\title{
Towards Learning for Employment: A Study of Effect of Different Variables on Employment Readiness of Students Enrolled in Professional Programmes Delhi-NCR, India
}

\author{
Khatri, Puja ${ }^{\text {a }}$ and Raina, Khushboo ${ }^{a}$ \\ ${ }^{a}$ University School of Management Studies, Guru Gobind Singh Indraprastha University, \\ India.
}

\begin{abstract}
Indian Higher Education system has got 70 million students enrolled in different technical and professional courses, which is highest in world. Being the fastest growing economy, India has got global attention also. Despite such strong foundation, the nation lacks a skilled workforce. The expectations of the industry don't match with what they receive as a workforce. There has been a continuous effort in instilling technical, communication, spiritual, leadership skills along with building a high quotient of ethics and professionalism in the students. The problem lies somewhere else, which needs quick attention. The present study attempts to analyze the effect of independent variables assessment of self competence, open to change, networking, professional growth, emotional growth, spiritual growth, realistic expectations, interpersonal skills, conceptual skills, technical skills, leadership skills, attitude towards planet, ethical disposition, flexibility to work and orientation towards money on the dependent variable Employment readiness through Regression analysis. The findings suggest that students need to assess their self competence, develop an achievement orientation attitude and work on technical skills in order to become Employment ready. There are very few studies addressing this issue in Indian context and researchers could find no published empirical work analyzing the effect of all these variables on Employment readiness. This would serve as a strong base for researchers in similar field. This study is beneficial for academicians, policy-makers and academic regulatory bodies.
\end{abstract}

Keywords: Employment readiness, Indian higher education, Gen Y employment readiness, Employability of Gen $Y$. 


\section{Introduction}

India has emerged out to be a hub of education attracting learners from around the globe. A massive expansion has taken place in Indian Higher Education system as it boasts of enrolling over 70 million students, highest in the world (FICCI, 2013). Despite having a strong institutional base, the emerging economies like India and China lack skilled workforce for MNCs (Multi National Corporations) as well as SMEs (Small \& Medium Enterprises) (Budhwar, 2004). Raina (2015) stated a study conducted by McKinsey across nine nations including India and found that only $42 \%$ of employers felt that the newly recruits were ready for jobs. According to the India skills report (2014), about $60 \%$ population of India is available for working and contributing towards economy but only $25 \%$ of them are actually capable of being used by the market. The focus remains on enhancing the hard skills of students ignoring the other aspects which may be significant for taking up a job and sustaining it. The present study attempts to analyze the areas which might be significant for students enrolled in professional courses, to learn skills which makes them Employment ready. This study is beneficial for academicians, policy-makers and academic regulatory bodies.

\section{Literature Review}

Ward, Riddle \& Lloyd (2004) define 'Employment readiness' as "being able, with little or no outside help, to find, get, and keep an appropriate job as well as to be able to manage transitions to new jobs as needed" (p.1 ).They further explain the factors critical to the success for one's work life: a) Employability measures (skill enhancement, job search, job maintenance, career decision making \& career management), b) Challenges (systemic, environmental \& personal) and c) Facilitators to support challenges (outcome expectancy, self-efficacy, work history \& social-support). Every nation differs in the type of skill set so required for making its youth employable. There is a difference of understanding the employment readiness as a construct .Management thinker Shiv Khera in his book "You can Win "focus on readiness for employment being understood in terms of right attitude which is mandatory for professional to be employment ready . Rhonda Byrne in her book "The secret " highlights that whatever we want in life can be achieved by dreaming ,working towards it and achieving it .Readiness for employment and work in the corporate world is also dependent on belief that somethings are destined. These can be seen as dreams or objectives which need to be fulfilled. This philosophy is endorsed again and again by eminent psychologists and social system whose preaching's suggest that one can carve out a place in life and be ready by believing in our dream and work towards competencies so as to get what is destined . So being employment ready also needs to create a dream and make it sure that it is destined to happen.(Jakes,2015) Professionals need to be groomed both emotionally and psychologically to be employment ready .Apart from this need is to find out the effect of individual variables like skill sets, spiritual and professional orientation ,networking, professional management etc. on the employment readiness of the budding Gen Y work force.

Gen $\mathrm{Y}$ budding professionals are dynamic and their workplace expectations range from good remuneration packages to flexible work options. They are tech-savvy and money- 
minded but understand the environmental concerns. Hamburg, Velden \& Verhagen (2013) describes some skills which are required in $21^{\text {st }}$ century for becoming a part of work force, they are interpersonal skills, innovative skills, professional expertise, academic skills \& entrepreneurial skills. Blom \& Saeki (2010) conducted a survey to analyze the employability levels of engineering graduates in India and what skills are necessary for them, they concluded that communication skills (verbal \& written), professional skills (cognitive skills \& aptitude to perform duties) and core skills for employment (general attitudinal \& affective skills). In order to make them employable the focus stays on their ethical disposition, developing skills like interpersonal, communication, leadership, professional attitude and perseverance (Junior Achievement Education, 2013). The researchers could find very few studies focusing on all these variables in Indian context and thus, this research will provide a sound foundation for researchers working in similar area. Though a clear understanding and literature is available for importance of types of skills, orientation towards growth ,networking etc. yet its relationship with employment readiness has not been explored .

\section{Research Methodology}

This research initiative studies the impact of perceptual inferences of students engaged in professional courses as regards a plethora of independent variables (IV's) like self competence, open to change, networking, professional growth, emotional growth, spiritual growth, realistic expectations ,importance of interpersonal skills, conceptual skills, technical skills, leadership skills, attitude towards planet, ethical disposition, flexibility to work and orientation towards money on the dependent variable (DV) Employment readiness. Regression analysis was conducted to observe the effect of various IV's mentioned above on the dependent variable (DV) Employment readiness. The dependent variable of employment readiness was mapped using a 12 item self constructed questionnaire. Requisite reliability and validity measures were adopted. The scale was put to factor analysis which resulted in two distinct and identifiable factors namely attitude towards growth and destiny .The questionnaire was constructed on a five point Likert agreement scale to measure the responses on the decided variables. The questionnaire was subjected to review by experts and their inputs have been incorporated accordingly. Reliability of the same was computed to be Cronbach Alpha (.975). According to Nunnally (1978, p. 245) the instruments used in basic research have reliability of about .70 or better. Our universe comprises all the institutions imparting professional and technical courses in Delhi-NCR region of India. The sampling was multistage. In the first place it was purposive wherein the researchers drew out a list of management and technical institutions affiliated by AICTE (All India Council for Technical Education). The list was generated through the web link http://trueguides.blogspot.in/2011/03/list-of-aicte-approved-collegesin.html. At second stage sampling was stratified wherein self financing management and technical institutes were selected from the list. Out of it, 2 management and 2 technical institutes were selected for the study. Final year students were administered questionnaires so as to record their perceptual inferences regarding skill set and ethical orientation. A total of 30 students per institute filled the questionnaires. Out of 120 filled questionnaires total of 107 completed questionnaires were taken for the study.

\section{Hypotheses}


There will be a significant effect of assessment of self competence, openness to change, networking, professional growth, emotional growth, spiritual growth, Attitude towards planet, interpersonal skills, Conceptual skills, Technical skills, leadership skills and ethical disposition on employment readiness of students engaged in professional courses.

\section{Results and Discussion}

The mean and standard deviations along with measures of skewness and kurtosis for each variable have been calculated. The variables were well within the threshold of skewness and kurtosis. To further investigate the normality of data we conducted KolmogorovSmirnov(KS) test of normality. The result showed that all variables are coming from a normal distribution. SPSS was used for the purpose of analysis. Regression was performed to find the significant effect of different independent variables (IVs)on employment readiness of students engaged in professional courses(DV).Employment readiness was measured in terms of attitude towards growth and destiny. Correlation analysis was done to understand the relationship between perception of Gen Y budding managers as regards their employment readiness (DV)and different other variables(IVs).It was observed that the perception about how ready the Gen Y mangers were for employment with the industry was highly correlated with their assessment of self competence $(r=.801, p<.01)$. Studies are there to support that throughout the socialization process the Indian student is exposed to the idea that whatever is destined to be will happen and that we should dare to dream .However it is believed on the other hand that it is pertinent to draw a link of perception about being successful with the ability to prioritize competencies required for fulfilling ones dream (Jakaes,2015) Strong relationship also existed between the aforesaid variable and assessment of Gen Y managers regarding their importance of the activities and training for the concept professional growth $(\mathrm{r}=.776, \mathrm{p}<.01)$ and spiritual growth $(\mathrm{r}=.508, \mathrm{p}<.01)$. However low correlations were recorded for the relationship between the DV and importance of interpersonal skills $(\mathrm{r}=.293, \mathrm{p}<.01)$ though it was highly correlated with the importance the respondents attached to conceptual $(\mathrm{r}=.715, \mathrm{p}<.01)$ and technical skills $(\mathrm{r}=.769, \mathrm{p}<.01)$. Moderate relationship was observed between the DV and the other IVs like importance of ethical disposition, importance of sensitivity training towards building realistic expectations from corporate, Attitude towards the planet and importance of understanding of networking.In other words destiny can be self constructed by enhancing self competence and skills. The belief that one is the engineer of his own destiny is a strong cultural input that a child gets from birth .Ironically however the system, education and family places greater impetus to harnessing social skills rather than technical. There are special lectures for interpersonal skill development wherein the importance of technical skills is diluted in most of the technical and professional curriculums. (Choudhury, 2014). To further investigate the effect of IVs on the DV through a stepwise regression analysis was done. The perception of Gen Y mangers regarding their assessment of self competence (ASC), importance of the activities and training for the concept professional growth(TFPG)and technical skills (TS)was calculated. The result is shown in table 1.1. Stepwise regression was used to determine the significance of each variable. This procedure has been used in previous studies (Hatten, Schendel \& Cooper, 1978;Eisenhardt $\&$ Schoonhoven, 1990). The model is significant which explains $64 \%$ of variability of employment readiness. According to the regression model the effect of assessment of self competence (ASC), importance of the activities and training for the concept professional growth(TFPG) $(\mathrm{B}=.31)$ and technical skills $(\mathrm{TS})(\mathrm{B}=.24)$ is positive, though the most 
significant contributor is assessment of self competence (ASC)wherein one unit improvement in Assesment of self competence results in 0.345 increase in employment readiness. $(\mathrm{B}=.345)$. Other IVs like to check for the existence of multicollinearity. Variance inflation factors (VIF) have been calculated and are observed to be well within the acceptable range hence, multicollinearity does not influence the results. Therefore, it can be concluded that the model is a good predictor of employment readiness of Gen Y budding managers.

Table 1. Model Summary

\begin{tabular}{|r|r|r|r|r|r|r|r|r|r|}
\hline Model & $\mathrm{R}$ & R Square & $\begin{array}{c}\text { Adjusted } \\
\text { R Square }\end{array}$ & $\begin{array}{c}\text { Std. Error } \\
\text { of the } \\
\text { Estimate }\end{array}$ & $\begin{array}{c}\text { R Square } \\
\text { Change }\end{array}$ & $\begin{array}{c}\text { F } \\
\text { Change }\end{array}$ & df1 & df2 & $\begin{array}{c}\text { Sig. F } \\
\text { Change }\end{array}$ \\
\hline 1 & $.801^{\mathrm{a}}$ & 0.641 & 0.638 & 0.40539 & 0.641 & 187.694 & 1 & 105 & 0 \\
\hline 2 & $.831^{\mathrm{b}}$ & \multicolumn{1}{|c|}{0.691} & 0.685 & 0.37804 & 0.05 & 16.745 & 1 & 104 & 0 \\
\hline 3 & $.841^{\mathrm{c}}$ & 0.707 & 0.699 & 0.36968 & 0.016 & 5.757 & 1 & 103 & 0.018 \\
\hline
\end{tabular}

a. Predictors: (Constant), assesmentofselfcompetence

b. Predictors: (Constant), assesmentofselfcompetence, professionalgrowth

c. Predictors: (Constant), assesmentofselfcompetence, professionalgrowth, Technicalskills

d. Dependent Variable: employmentreadiness

Table 2. Coefficients

\begin{tabular}{|c|c|c|c|c|c|c|c|c|}
\hline \multirow[b]{2}{*}{ Model } & & \multicolumn{2}{|c|}{$\begin{array}{c}\text { Unstandardized } \\
\text { Coefficients }\end{array}$} & \multirow{2}{*}{$\begin{array}{c}\begin{array}{c}\text { Standardized } \\
\text { Coefficients }\end{array} \\
\text { Beta }\end{array}$} & \multirow[b]{2}{*}{$\mathrm{t}$} & \multirow[b]{2}{*}{ Sig. } & \multicolumn{2}{|c|}{ Collinearity Statistics } \\
\hline & & B & Std. Error & & & & Tolerance & VIF \\
\hline \multirow[t]{2}{*}{1} & (Constant) & 0.406 & 0.268 & & 1.513 & 0.133 & & \\
\hline & assesmentofselfcompetence & 0.893 & 0.065 & 0.801 & 13.7 & 0 & 1 & 1 \\
\hline \multirow[t]{3}{*}{2} & (Constant) & 0.173 & 0.256 & & 0.675 & 0.501 & & \\
\hline & assesmentofselfcompetence & 0.557 & 0.102 & 0.5 & 5.465 & 0 & 0.355 & 2.818 \\
\hline & professionalgrowth & 0.38 & 0.093 & 0.374 & 4.092 & 0 & 0.355 & 2.818 \\
\hline \multirow[t]{3}{*}{3} & (Constant) & 0.229 & 0.252 & & 0.908 & 0.366 & & \\
\hline & assesmentofselfcompetence & 0.384 & 0.123 & 0.345 & 3.123 & 0.002 & 0.233 & 4.291 \\
\hline & professionalgrowth & 0.321 & 0.094 & 0.317 & 3.418 & 0.001 & 0.331 & 3.022 \\
\hline
\end{tabular}




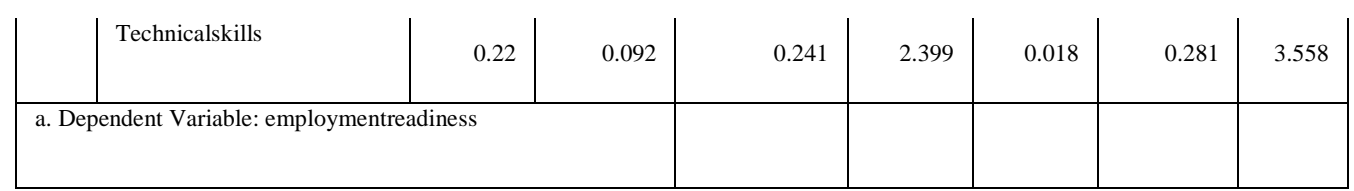

\section{Conclusions and Implications}

There is no denying to the fact that there exists a skill gap between what industry expects of students and what they have to offer. Around $80 \%$ of engineering graduates are unemployable (Times of India, 2016). Millions of students graduate ever year but more than $50 \%$ of them are not employable. The academia and institutes imparting higher professional education feel that the skills that make a student employable are problem solving attitude, team-player, leadership capabilities, adaptive to changes, basic technical knowledge, communication skills and creativity (Panse, n.d.). The institutes are focusing all effort in harnessing these skills and thereby preparing the Gen Y workforce to be smart workers wherein the importance of technical knowledge, right attitude and self confidence and competence is relegated a back seat. However as per the students who are in the process of learning towards development into an employable workforce are having a different perspective. The research findings indicate that importance of clear assessment of self competence is the key. It has emerged out to be the most important factor in determining the Gen Y employment readiness. More so the budding professionals link their dreams and destiny along with growth orientation in terms of prioritizing what they require for fulfilling their dreams and know clearly that it is dependent on their attitude towards self, growth attitude and technical skill proficiency which however is not catered to by the system of higher professional education in its current form. Talking of skill development, prime minister of India Mr. Narendra Modi stated that employment creation and skill development are the main priorities of Indian Govt. so that this gap is acknowledged. Further, mentioning the percentage of available skilled workforce in India, he pointed out that less than $4 \%$ of its population is skilled as compared to South Korea (96\%), Japan (80\%), China (47\%) and Germany (74\%) (Nanda, 2015).It is the need of the hour to develop a positive attitude towards oneself \& the way they are also learnt ,are very important (Schein, 1967). Gen Y feels that the right impetus should be given to imparting on the job technical knowledge to make them more job ready for a dynamic industry. Though the curriculum followed is age old and doesn't fit the expectations of recruiters anymore. The technical knowledge is not as per industry standards, which is a cause of worry for our budding professionals. There is an immediate need of revising the curriculum and teaching methods (Choudhury, 2014). Employability skills can be taught at institutional or job level as they are teachable (Robinson, 2000). Learning hard and soft skills will make them street-smart. However, the superficial knowledge in their respective domains leads to low motivation and low self-assessment and thereby leading to inability to visualize their dreams, believe in themselves and develop a growth orientation so as to be employable. Sensitivity training must be imparted to students in order to inculcate sound professionalism and positive attitude in them thereby helping them to carve their own destinies. Due to right orientation given by some premiere institutes, their students are winning the race with lucrative packages. Whereas, students from other institutes are lagging behind because they think they are not competent enough to grab a dream job or remuneration equivalent to those from premiere institutes. There is an urgent need to bridge this increasing gap of learning requirements by all stake holders like institutions, 
regulatory bodies, administrators, parents and policy makers. Our research can be instrumental in giving insights to institutions to rework on their learning modules and their processes of implementation so as to draw a vivid and objective path towards learning for employment.

\section{Limitations of the Study and Areas of Further Research}

No work is accomplished without precincts, because margins open the way for further growth. Size of sample was a constraint and major limitation of the study. Comparisons may also be done between 2tier, 3 tier cities and metropolitan cities as this research is limited only to Delhi NCR.

\section{References}

Blom, A. and Saeki, H. (2010). Employability and Skill Set of Newly Graduated Engineers in India, Retrieved from http://www.npiu.nic.in/PDF/Mentoring\%20and\%20Audting/BEmploybility\%20and\%20Skill\%20set $\% 20$ of $\% 20$ newly $\% 20$ graduated $\% 20$ engineers $\% 2$ 0in\%20India.pdf (accessed January 25, 2016).

Budhwar, P. (2004). Managing Human Resources in Asia-Pacific. London, UK: Routledge. Byrne, R. (2006). The Secret. New York, USA: Atria Books Beyond Words Publishing.

Eisenhardt, K. and Schoonhoven, C.B. (1990). Organizational Growth: linking founding team strategy, environment and growth among US semiconductor ventures, Administrative Science Quarterly, Vol. 35, No. 3, pp. 504-529.

FICCI (2013). Higher Education in India, Vision 2030: FICCI Higher education summit 2013, Retrieved from http://www.ey.com/Publication/vwLUAssets/Higher-educationin-India-Vision-2030/\$FILE/EY-Higher-education-in-India-Vision-2030.pdf (accessed January 25, 2016)

Hatten, K.J., Schendel, D.E. and Cooper, A.C. (1978). A strategic model of the United States brewing industry, Academy of Management Journal, Vol. 21, No. 4, pp. 592-610.

Humburg, M., Velden, R.v.d. and Verhagen, A. (2013). The Employability of Higher Education Graduates:The Employers' Perspective, School of Business and Economics, pp. 15-131.

Jakes, T.D. (2015). Destiny. New York, USA: Faith words.

Khera, S. (1998). You can win. Chennai, India: McMillan Publishers India.

Nanda, P.K.(2015). Employment generation, skill development top priorities: Narendra Modi, Live-Mint, Thursday, July 16, 2015.

Nunnally, J. C. (1978). Psychometric theory (2nd ed.). New York, NY: McGraw-Hill.

$\operatorname{OECD}(2014)$. Giving youth a better start, Retrieved from http://www.oecd.org/mcm/CMIN(2014)18-ENG.pdf (accessed January 22, 2016)

Panse, V.B. (n.d.). Employability of Indian graduates, Retrieved from https://mygov.in/sites/default/files/user_submission/affbde65ea4419e74d5ceb6188e8fb 14.pdf (accessed January 28, 2016).

Raina, S. (2015). Bridging the skills gap. The smart manager, January-February 2015, pp. 75-79.

Schein, Edgar H.(1967). Attitude change during Management Education. Administrative Science Quarterly, Vol. 11(4), Special Issue on Universities as Organizations, pp. 601628.

Robinson, J.P. (2000). The workplace, Alabama cooperative extension system, Vol 1, Iss. 
3, pp. 1-3.

Sarkar, A.K. and Choudhury, S.K. (2014). Reasons for low employability of engineering graduates, Retrieved from http://www.businesstoday.in/opinion/deep-dive/a.-k.-sarkars.k.-choudhury-on-engineering-students-employment/story/205041.html (accessed January 28, 2016).

The India Skills Report (2014). Retrieved from https://wheebox.com/wheebox/resources/IndiaSkillsReport.pdf (accessed January 25, 2016).

Times of India (2016). Over $80 \%$ of engineering graduates in India unemployable: Study, Retrieved from http://timesofindia.indiatimes.com/tech/tech-news/Over-80-ofengineering-graduates-in-India-unemployable-Study/articleshow $/ 50704157 . \mathrm{cms}$ (accessed January 28, 2016).

Ward, V.G., Riddle, D.I. and Lloyd, D. (2004). Maximizing Employment Readiness. NATCON papers 2004, Les actes de la CONAT, 2004. 